\title{
Malnutrition affects the pressor response to microinjection of L-glutamate into the RVLM of awake rats
}

\author{
Fabiana Aparecida Rodrigues ${ }^{1}$; Deoclecio Alves Chianca-Jr² and Luciano Gonçalves Fernandes ${ }^{3 *}$ \\ ${ }^{1}$ Nucleus of Biological Research (NUPEB), Federal University of Ouro Preto (UFOP). Ouro Preto, MG, Brazil - 35400-000. \\ 2 Department of Biological Sciences, Federal University of Ouro Preto (UFOP). Ouro Preto, MG, Brazil - 35400-000. \\ ${ }^{3}$ Department of Physiological Sciences, Federal Rural University of Rio de Janeiro (UFRRJ). Seropédica, RJ, Brazil - 23890-000.
}

\begin{abstract}
Post-weaning protein malnutrition is often related to the development of cardiovascular and metabolic diseases in humans, as well to changed content of neurotransmitters in the central nervous system under experimental conditions. The rostral ventrolateral medulla (RVLM) is a bulbar region that contains sympathetic premotor neurons; the excitatory amino acid L-glutamate seems to be the main neurotransmitter at this level. The aim of the present study was to evaluate the possible change in the L-glutamate sensitivity of the RVLM neurons of malnourished animals. Male Fischer rats were divided into two groups: control $(n=15)$ and malnourished $(n=19)$. Four days before the experiments, guide cannulas were implanted bilaterally in direction of the RVLM for microinjection of L-glutamate. Twenty-four hours before the experiments, the femoral artery was cannulated for cardiovascular recordings. The results showed that the baseline heart rate increased in malnourished compared to control animals (412.18 $\pm 16.03 \mathrm{bpm} v s .370 .74 \pm 9.59 \mathrm{bpm}$, respectively). Malnourished animals presented a dissimilar concentration-dependent pressor response curve to L-glutamate and an attenuated baroreflex gain. Our results suggest that post-weaning protein restriction affects glutamatergic neurotransmission of the baroreflex at the RVLM level.
\end{abstract}

Key terms: baroreflex, blood pressure, L-glutamate receptors, heart rate, malnutrition, RVLM.

\section{INTRODUCTION}

Malnutrition denotes a nutritional state in which the diet does not provide adequate calories and protein for growth and organic maintenance (UNICEF, 2011). According to the World Health Organization, malnutrition is the biggest contributor to child mortality; hunger, underweight births and intra-uterine growth restrictions cause 2.2 million child deaths a year. (World Health Organization, 2009). Besides causing mortality, malnutrition often leads to morbidity. Studies from the literature (Cohen, 2004; Sawaya et al., 2003) suggest that a period of malnutrition during early childhood is directly related to development of hypertension and metabolic imbalance in adult life. These observations are in accordance with the "nutritional programming" hypothesis for cardiovascular diseases (Barker, 2007; Benabe and MartinezMaldonado, 1993; Roseboom et al., 1999; Roseboom et al., 2000; Roseboom et al., 2000b).

Previous studies from our lab have shown that afterweaning malnutrition affects neural mechanisms involved in cardiovascular homeostasis (Bezerra et al., 2011a; Bezerra et al., 2011b; Loss et al., 2007; Martins et al., 2011; Oliveira et al., 2004; Penitente et al., 2007; Tropia et al., 2001). While the exact mechanism remains to be understood, there is evidence indicating that malnutrition can affect the release of neurotransmitters and receptor affinity in several areas of the central nervous system (El et al., 1999; Gotoh et al., 1996; Seidler et al., 1990) The rostral ventrolateral medulla (RVLM) is a bulbar site among the neural pathways of cardiovascular reflexes (e.g., baroreflex); it contains reticulo-spinal neurons that innervate the pre-ganglionic sympathetic neurons (Ross et al., 1984). According to anatomical (Aicher et al., 1995; Ross et al., 1984) and experimental evidence (Lipski et al., 1996a; Lipski et al., 1996b; Sun et al., 1988a; Sun et al., 1988b; Sun et al., 1988c), it is well accepted that neurons located in the RVLM are involved in the maintenance of arterial pressure within levels compatible with life, through modulation of sympathetic activity. The RVLM has been associated with pathophysiological mechanisms that cause cardiovascular diseases (Colombari et al., 2001; Dampney et al., 2003; Guyenet, 2000).

Although there is evidence that malnutrition affects the cardiovascular system, there are few studies addressing the impact of malnutrition on the CNS areas involved in cardiovascular neural reflexes. Based on the assumption that the RVLM is a key region for sympathetic efferent activity and that L-glutamate is the major excitatory neurotransmitter in this area (Machado et al., 1997), the main objective of the present study was to evaluate the impact of malnutrition on the pressor response to microinjection of L-glutamate into the RVLM of freely moving malnourished rats.

\section{METHODS}

Animals

Male Fischer rats were used in this study. After birth, the offspring were randomly chosen and eight pups per dam were kept. The five dams used in the present study received normal rat chow ( $15 \%$ protein content) and water ad libitum. The pups were weaned after 28 days and then the males were divided into two groups according to the diet received; the control group received a diet containing $15 \%$ protein, and the experimental malnourished group received a diet containing 
only $6 \%$ protein. Both groups received this diet for the next 35 days, after which the rats were weighted. During the following seven days, the rats underwent experimental protocols and continued receiving experimental rat chow (normal or low protein diet) according to the experimental group. The low protein diet was isocaloric with respect to the control diet. All the components of the diets were purchased from Rhoster (São Paulo, Brazil). During all experimental protocols, the rats remained in controlled laboratory conditions (12/12 h light/ darkness cycle, temperature: $23-25^{\circ} \mathrm{C}$ ). There were 15 control rats and 19 malnourished rats. All the experimental protocols followed the guidelines of the Brazilian Society for Laboratory Animal Science (SBCAL).

\section{Stereotaxic surgery}

Under tribromoethanol anesthesia through a stereotaxic apparatus (David-Kopf, Tujunga, CA, USA), the rats were submitted to stereotaxic surgery and guide cannulae were implanted in the direction of the RVLM bilaterally, according to stereotaxic coordinates adapted from (Paxinos and Watson, 2007): $3.9 \mathrm{~mm}$ caudal to the Lambda; $8.0 \mathrm{~mm}$ below the skull surface and $1.8 \mathrm{~mm}$ lateral to the midline for the control rats, and $2.9 \mathrm{~mm}$ caudal to the Lambda; $7.0 \mathrm{~mm}$ below the skull surface and $1.7 \mathrm{~mm}$ lateral to the midline for the malnourished rats. The $15 \mathrm{~mm}$-long guide cannulae were made from hypodermic needles $(25 \times 0.7 \mathrm{~mm})$. The needles used for microinjections were made from 30 gauge needles (Unoject, Rio de Janeiro, RJ, Brazil) and were 2.0-2.5 mm longer than the guide cannulae. In order to perform microinjections in the RVLM, the microinjector needle was connected to a $1 \mu \mathrm{L}$ syringe (Hamilton, Reno, NV, USA) through a PE-10 catheter (Clay Adams, Parsippany, NJ, USA). Each microinjection had a volume of $50 \mathrm{~nL}$.

\section{Cannulation of the femoral artery}

Five days after the stereotaxic surgery, the animals were submitted to a second anesthetic protocol to insert a polyethylene catheter into the abdominal aorta through the femoral artery. Under tribromoethanol anesthesia $(2.5 \%, 1$ $\mathrm{mL} / 100$ g, i.p.), a polyethylene catheter (PE-10 connected to PE50; Clay Adams, Parsippany, NJ, USA) filled with heparinized saline was inserted into the abdominal aorta, through the left femoral artery, for measurement of pulsatile arterial pressure (PAP). The free end of the catheter was tunneled subcutaneously and emerged through the back of the neck.

\section{Cardiovascular measurements}

The next day, the animals were placed in the experimental room between 7:00 and 8:00 AM to allow them to acclimatize to the experimental room. At the time of cardiovascular recordings (at 1:00 to 1:30 PM), the arterial catheter was connected to a pressure transducer (Model MLT0699; ADInstruments Pty Ltd., Castle Hill, NSW Australia). It is important to emphasize that during the cardiovascular recordings, all animals were fully recovered from surgery and anesthesia protocols. Data were obtained through an analog-to-digital data acquisition system (Model PowerLab 400; ADInstruments Pty Ltd., Castle Hill, NSW, Australia) and were sampled at 12 bits using a $200-\mathrm{Hz}$ sampling rate. Heart rate (HR) and mean arterial pressure (MAP) were derived offline from PAP using the Chart for Windows software, version 4.1.2 (ADInstruments Pty Ltd., Castle Hill, NSW, Australia). The baseline of cardiovascular variables, MAP and HR were recorded during the $15 \mathrm{~min}$ before each experimental trial. All trials were performed on conscious and unrestrained rats.

Dose-response curve to L-glutamate microinjection into the RVLM

After stabilization of the cardiovascular parameters, solutions of L-glutamate ( $1 \mathrm{fM}, 10 \mathrm{fM}, 100 \mathrm{fM}, 1 \mathrm{pM}, 10 \mathrm{pM}, 100 \mathrm{pM}, 1$ $\mathrm{nM}, 10 \mathrm{nM}, 100 \mathrm{nM}$ ) were microinjected in random order. Each animal received at most three microinjections of L-glutamate or aCSF (artificial cerebrospinal fluid) in the RVLM in order to avoid extensive damage to the neural tissue. According to previous studies (Gotoh et al., 1996a; Patel et al., 2008) the physiological concentration at the RVLM of rats is $67 \mathrm{nM}$. Therefore, the physiological concentration is in the range of the concentrations of L-glutamate used in the present study.

Drugs and microinjections

L-Glutamate was dissolved in artificial cerebrospinal fluid (aCSF) in order to obtain final solutions in the following concentrations: $1 \mathrm{fM}, 10 \mathrm{fM}, 100 \mathrm{fM}, 1 \mathrm{pM}, 10 \mathrm{pM}, 100 \mathrm{pM}, 1 \mathrm{nM}$ and $10 \mathrm{nM}$. The aCSF contained (in $\mathrm{mM}$ ) $150 \mathrm{NaCl}, 5 \mathrm{KCl}, 1$ $\mathrm{MgCl} 2,2 \mathrm{CaCl} 2,10$ HEPES, and 10 glucose ( $\mathrm{pH}$ was adjusted to 7.4 with Trisma-base). All microinjections were made in a volume of $50 \mathrm{~nL}$. All drugs and salts were purchased from Sigma-Aldrich Chemical (St. Louis, MI, USA).

\section{Histology}

At the end of the experiments, the rats were sacrificed with an overdose of sodium thiopental (Abbot Laboratories, USA) and perfused with saline followed by $10 \%$ formalin. The brains were removed, stored in formalin for at least 48 hours and sliced in $40 \mu \mathrm{m}$ thick coronal sections in a cryostat (Leica). Sections were stained with neutral red stain for histological analysis and only the brains of rats with positive sites of microinjections in the RVLM were used. In the histological analysis we identified the path of the microinjector needle in direction to the RVLM as well the center of the microinjections.

\section{Data analysis}

After histological confirmation of the correct microinjection site, we analyzed the following cardiovascular parameters from each positive animal: a) baseline mean arterial pressure and heart rate before any microinjection, $b$ ) pressor response to microinjection of L-glutamate in the RVLM and c) $\Delta \mathrm{HR}$ (bpm) / $\triangle \mathrm{MAP}(\mathrm{mmHg})$ (first derivative of the baroreflex function) as a bradycardic index to estimate baroreflex gain activated by the pressor response to L-glutamate microinjection in the RVLM of awake rats.

\section{Statistical analysis}

The data were represented as mean \pm SEM and were analyzed by the paired Student t-test followed by Bonferroni post-test or one-way for repeated measures, followed by the Tukey post-test as needed. In all analyses, the significance level was fixed at 5\%. 


\section{RESULTS}

\section{Impact of malnutrition on body weight}

In the present study we observed that the post-weaning protein restriction reduced the body weight of the malnourished rats by $70 \%$ in comparison to the control group $\left(78.05 \pm 3.6 \mathrm{~g}\right.$ vs. $256.3 \pm 7.72 \mathrm{~g}$, respectively) on the $35^{\text {th }}$ day of low protein feeding. This result has been observed in previous studies from our lab and has been recognized as a validation for our malnutrition protocol.

Effect of malnutrition on baseline heart rate and mean arterial pressure

For the analysis of the baseline mean arterial pressure and heart rate, we selected 15 minutes of cardiovascular recordings before any central manipulation. The mean basal HR levels in the malnourished group were significantly higher in comparison with those observed in the control group (412.18 $\pm 14.25 \mathrm{bpm}$ vs. $370.74 \pm 9.59 \mathrm{bpm}$, respectively). Regarding the mean arterial pressure, there was no difference in basal levels observed in the malnourished group compared to the control group $(109.24 \pm 4.74 \mathrm{mmHg}$ vs. $108.58 \pm 2.87 \mathrm{mmHg}$, respectively).

Cardiovascular changes subsequent to L-glutamate microinjection into the RVLM of awake rats

Figure 1 represents changes in MAP $(\mathrm{mmHg})$ following microinjections of different concentrations of L-glutamate in the RVLM of malnourished and control rats. We observed the following pressor responses to each L-glutamate solution microinjected in the RVLM: 1 fmol: $8.35 \pm 0.95$ vs. $6.3 \pm 1.4$ $\mathrm{mmHg}$, 10 fmol: $16.025 \pm 2.19$ vs. $6.13 \pm 3.03 \mathrm{mmHg}, 100 \mathrm{fmol}$ :

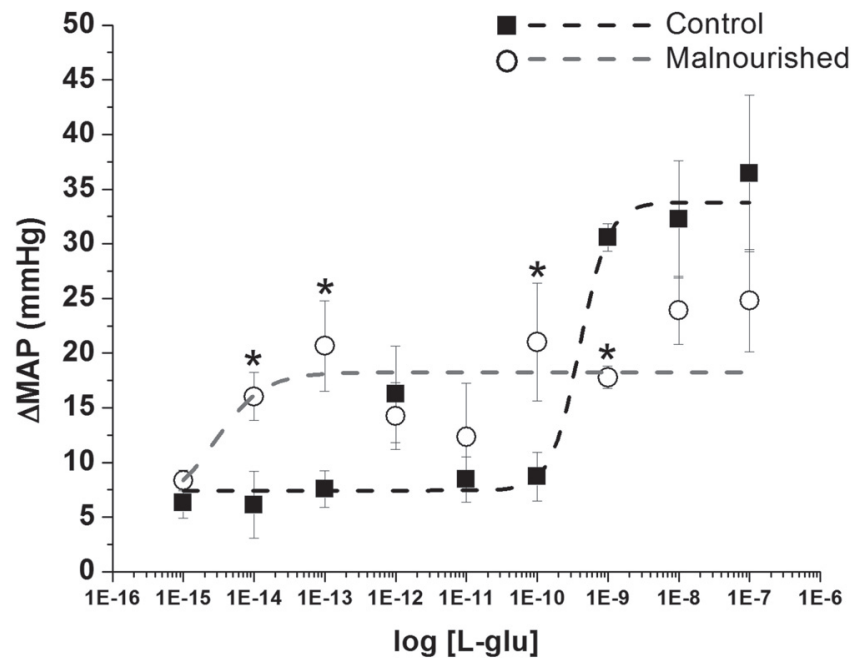

Figure 1: Concentration-pressor response curve $(\mathrm{mmHg})$ obtained after the microinjecton of different concentrations of L-glutamate (1fM, 10fM, 100fM, 1pM, 10pM, 100 pM, 1nM, $10 \mathrm{nM}$ and $100 \mathrm{nM}$ ) into the RVLM of control (black squares, $n=15$ ) and malnourished (white circles, $n=19$ ) rats $(*=$ different from the control, same concentration; $\mathrm{p}<0.05$ ). The dashed lines represent a sigmoidal regression of the data of the control (black line) and malnourished (gray line) groups.
$20.66 \pm 4.12$ vs. $7.57 \pm 1.64 \mathrm{mmHg}, 1$ pmol: $14.23 \pm 3.07$ vs. 16.23 $\pm 4.43 \mathrm{mmHg}, 10$ pmol: $12.32 \pm 4.9$ vs. $8.45 \pm 2.05 \mathrm{mmHg}, 100$ pmol: $21.02 \pm 5.39$ vs. $8.7 \pm 2.23 \mathrm{mmHg}, 1 \mathrm{nmol}: 17.78 \pm 1.01$ vs. $30.6 \pm 1.25 \mathrm{mmHg}$, 10 nmol: $23.92 \pm 3.11$ vs. $32.24 \pm 5.35 \mathrm{mmHg}$, 100 nmol: $24.8 \pm 4.68$ vs. $36.43 \pm 7.15 \mathrm{mmHg}$ in malnourished and control rats, respectively. As a volume control, aCSF was microinjected in the RVLM of awake malnourished or control rats and we observed that this vehicle produced negligible effects on the MAP of both groups.

\section{Baroreflex gain to L-glutamate microinjection into the RVLM}

From each animal we selected a period of cardiovascular recordings including a baseline MAP and HR as well as the observed changes in MAP and HR subsequent to L-glutamate microinjection into the RVLM. These data were plotted and fitted in the following sigmoid logistic equation:

$$
H R=\frac{H R \max +(H R \max -H R \min )}{1+e^{\frac{M A P 50-M A P}{p}}}
$$

Here HRmax stands for the upper plateau, HRmin represents the lower plateau, MAP50 is the MAP value at the midpoint of the $H R$ range and $p$ is the curvature. As a result, we obtained a baroreflex sigmoid curve. These data are summarized in Figure 2, which shows that malnourished animals present altered baroreflex function in comparison to control rats. We also determined the continuous baroreflex gain function by calculating the first derivative of the baroreflex curve in the range of the baroreflex sigmoid function, applying the formula:

$$
y^{\prime}=\lim _{\Delta M A P \rightarrow 0} \frac{\Delta H R}{\Delta M A P}
$$

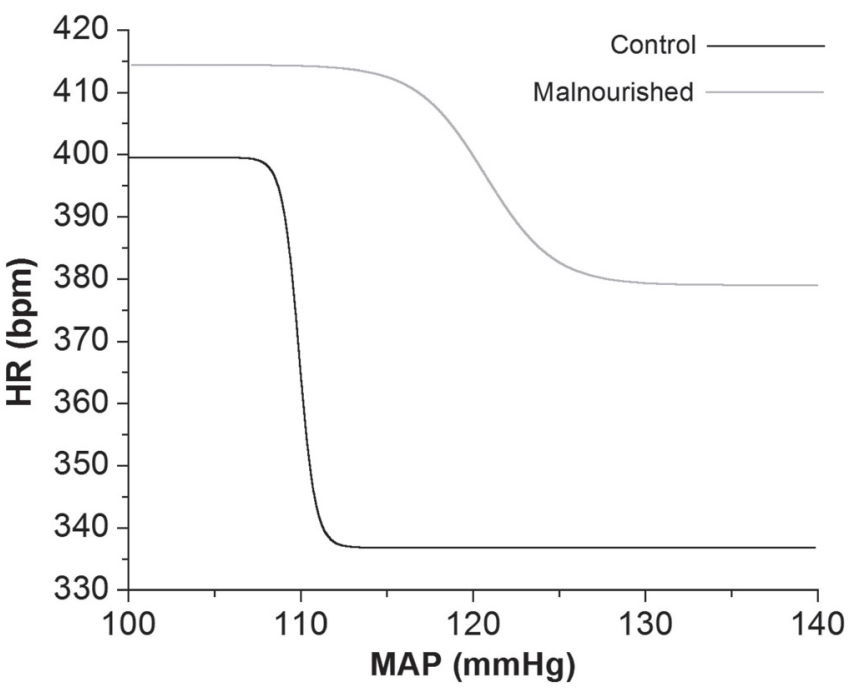

Figure 2: Baroreflex sigmoid curve of the control (black line, $\mathrm{n}=15$ ) and malnourished rats (gray line, $\mathrm{n}=19$ ). 
Where $\mathrm{y}^{\prime}$ represents the baroreflex gain (in bpm/ $\mathrm{mmH}$ ), $\triangle \mathrm{HR}$ the heart rate difference and $\triangle \mathrm{MAP}$ the MAP difference. The highest baroreflex gain occurred at the MAP of 109.8 $\mathrm{mmHg}$ for the control animals at the rate of $-32.9 \mathrm{bpm} / \mathrm{mmHg}$, whereas the peak baroreflex gain occurred at $120.82 \mathrm{mmHg}$ for the malnourished rats at the rate of $-4.38 \mathrm{bpm} / \mathrm{mmHg}$. The range of baroreflex gain can be assessed by this analysis; for the control group it was between 105.9 and $113.8 \mathrm{mmHg}$, while for the malnourished group it ranged from 108.8 to 130.16 $\mathrm{mmHg}$. The data concerning this analysis are summarized in Figure 3.

\section{DISCUSSION}

The present study was undertaken to evaluate the sensitivity of the RVLM to L-glutamate of malnourished and control rats. We observed that rats submitted to malnutrition after weaning presented impaired sensitivity to L-glutamate microinjection in the RVLM. Moreover, the present study shows that the baroreflex gain is attenuated in rats submitted to protein restriction.

First, it is important to point out that our study was performed in awake and freely moving rats. This preparation is closer to the real physiological condition, since there is no influence of anesthetics on autonomic activity. It has been shown that the use of any anesthetic profoundly impacts the neural pathways of cardiovascular reflexes (Machado and Bonagamba, 1992). Also, it is important to note that the low protein diet used here had no calorie restriction, since it was isocaloric to the control diet.

The RVLM contains neurons whose activity seems to be related to the patterns observed in sympathetic vasomotor nerves. Therefore, those neurons are sensitive to changes in the main arterial pressure and show a pulse modulated activity at high levels of arterial pressure (Brown and Guyenet, 1985; Lipski et al., 1995; Lipski et al., 1996b; Morrison et al., 1988). The majority of these neurons project directly and/

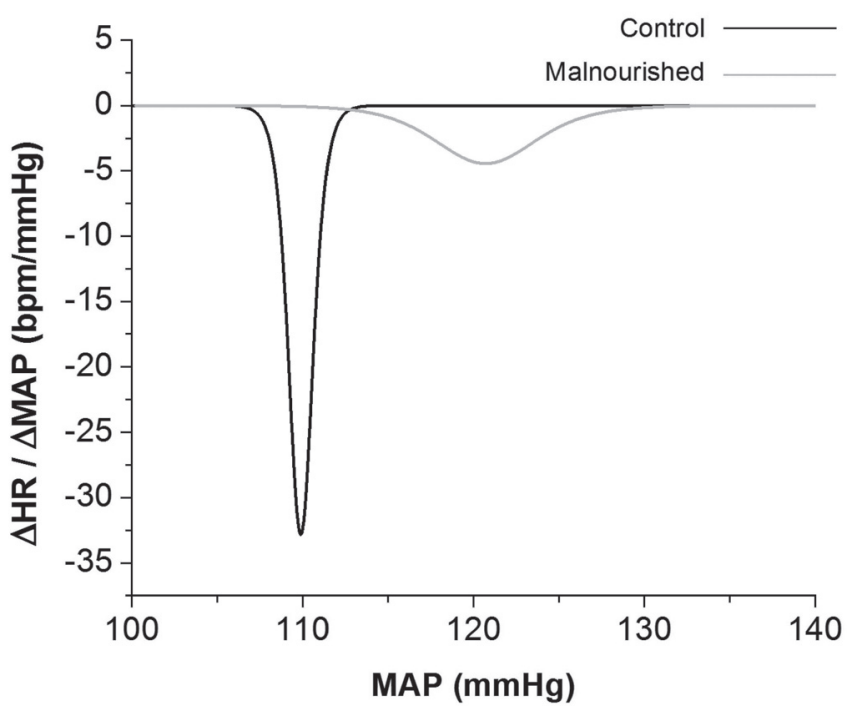

Figure 3: Baroreflex gain (expressed as $\mathrm{bpm} / \mathrm{mmHg}^{2}$ ) associated with the pressor responses secondary to microinjection of different concentrations of L-glutamate into the RVLM of the control (black line, $n=15$ ) and malnourished (gray line, $n=19$ ) rats. or indirectly to the spinal cord, where they innervate the preganglionic sympathetic neurons (Milner et al., 1988; Ross et al., 1984). Under resting conditions, RVLM neurons are tonically inhibited by GABAergic afference from the caudal ventrolateral medulla - CVLM (Dampney, 1994; Schreihofer and Guyenet, 2002). Guertzenstein and Silver, (1974) depicted the RVLM as an important medullary region for the control and maintenance of baseline mean arterial pressure. It is therefore accepted that the excitatory premotor neurons of the RVLM are critical to maintain the activity of preganglionic sympathetic neurons (Dampney et al., 2003b; Dampney and Horiuchi, 2003). Most studies regarding the role of the RVLM in the maintenance of vasomotor sympathetic activity were conducted on anesthetized animals; stimulation of the RVLM increased the baseline mean arterial pressure (Bergamaschi et al., 1995; Campos and McAllen, 1999; McAllen, 1986), while bilateral lesions of the RVLM region reduced the baseline mean arterial pressure to levels similar to those observed after spinal cord transection (Dampney, 1994; Feldberg and Guertzenstein, 1976; Guertzenstein and Silver, 1974). On the other hand, a study (Cochrane and Nathan, 1989) observed that the cardiovascular responses to RVLM inhibition depended on the type of anesthetic protocol used, and the study of Bachelard et al. (1990), showing that chemical stimulation of the RVLM in conscious rats elicited a pressor response, raised the importance of investigating the role of RVLM in maintaining blood pressure in awake animals. Araujo et al. (1999) confirmed that the chemical stimulation of the RVLM with L-glutamate elicits a pressor response in awake rats. Therefore, the present study was conducted in awake and freely moving rats.

The first observation of the present study is that the microinjection of L-glutamate into the RVLM of malnourished rats provokes smaller pressor responses in comparison to those observed in control rats. In agreement with this observation, several studies in the literature report that malnutrition, irrespective of the model used, can cause changes in the neurotransmitter concentration in the CNS, in neurotransmitter/receptor affinity (Gotoh et al., 1996; Plagemann et al., 2000; Plagemann et al., 2006; Seidler et al., 1990; Zippel et al., 2003) and in the neuronal population and/or CNS nucleus morphology (Plagemann et al., 2000; Plagemann et al., 2006). These alterations may be responsible for deficits in memory and learning (Gray, 1989; Gray and Gray, 1989; Hall et al., 1983; Hall, 1983; Plagemann et al., 2000; Plagemann et al., 2006), motor activity (Gallo, 1981; Plagemann et al., 2000; Plagemann et al., 2006), affective behavior (Gallo, 1981; Hall et al., 1983; Hall, 1983), endocrine (Benabe and Martinez-Maldonado, 1993; Plagemann and Harder, 2009; Sawaya et al., 2003) and cardiovascular systems (Loss et al., 2007; Penitente et al., 2007; Tropia et al., 2001) observed in malnourished animals. Therefore, these changes in neurotransmitter release and/or receptor affinity may also be responsible for the impact of malnutrition on the cardiovascular system. Allied to this, rats submitted to protein malnutrition after weaning present increased pressor response to chemoreflex activation (Penitente et al., 2007), another important cardiovascular reflex. Loss et al. (2007) showed that the onset of the sympathoexcitation and parasympathoexcitation effects is changed in malnourished rats. These observations strengthen the hypothesis of an altered autonomic modulation in animals submitted to malnutrition. 
As depicted in Figure 2, the baroreflex curve is attenuated and shifted upward in malnourished animals, denoting malfunctioning of this important cardiovascular reflex in malnourished rats. We also analyzed the dynamic range of baroreflex gain and it was far greater in the malnourished than in the control rats. This is also reflected by the maximum baroreflex gain; while it occurred at normal levels in the control animals, the peak gain occurred at larger values in the malnourished animals. Moreover, although the baseline heart rate was greater in the malnourished animals in comparison to the control rats, the activation of baroreflex promoted by the pressor response to microinjection of L-glutamate into the RVLM and the subsequent sympathoinhibition directed to the heart (associated with parasimpathoexcitation) produced only minor heart rate changes in the malnourished animals. This suggests that rats submitted to malnutrition present increased efferent sympathetic tonus. This is in accordance with previous study from our lab (Martins et al., 2011) which indicate that the low-frequency component of the heart rate variability is increased in malnourished rats. The increased sympathetic tonus was also suggested by Penitente et al (2007), so this may be responsible for the reduction in the baroreflex gain and range observed in these animals, and therefore for the increased baseline heart rate.

As limitations of the present study, we should consider that changes in the pressor response to L-glutamate microinjection into the RVLM could represent the impacts of malnutrition on the blood volume, cardiac output or structural changes of the peripheral vascular system. Moreover, the model of protein restriction used in the present study reflects a condition that very seldom is seen in humans (Sawaya et al., 2003). Our experimental model was formulated for the study of post-weaning protein restriction. Therefore, the rats were submitted to protein restriction beginning 28 days after birth, which is when weaning normally occurs. This model reflects a situation that occurs in many countries, where the newborn have adequate protein intake through breast feeding, but after weaning (which can be premature in some cases) the protein intake is greatly reduced because it is the most expensive diet component. There are few studies addressing post-weaning protein restriction, although the group of Dr. Sawaya has observed that teenagers from Brazilian slums are stunted and prone to develop metabolic and cardiovascular diseases (da Luz Santos et al., 2010; Franco et al., 2008) Moreover, this model seems to be a validated model to study the effects of protein restriction in a critical period of development on the occurrence of cardiovascular and metabolic diseases in adult life (Sawaya et al., 2003c). The changes in the pressor response to L-glutamate microinjection in the RVLM and in the baroreflex gain could be caused by changes in the neurotransmission and by changes in the neuronal morphology as well. In this regard, several studies have shown that malnutrition leads to changes in neurotransmitter systems (Benabe and Martinez-Maldonado, 1993; Seidler et al., 1990; Zippel et al., 2003). Moreover, Plagemann et al. $(2000,2006)$ showed that malnutrition causes malformations in the CNS nuclei involved in cardiovascular regulation. On the other hand, with our results we cannot assure whether this is the case in our experimental model of malnutrition. Further studies are needed to clarify this possibility. Also, there may be differences related to these two experimental models. Studies suggest that malnutrition during discrete periods of life (e.g., gestation, lactation, during weaning and after weaning) can produce different levels of homeostasis imbalance; nevertheless, there is a consensus that protein deprivation in any period of life can lead to cardiovascular and metabolic imbalances (Barker, 2007; Cohen, 2004; El et al., 1999; Gallo, 1981; Oliveira et al., 2004; Roseboom et al., 1999). Unfortunately, there are few studies addressing post-weaning protein malnutrition and most of them are from our group. Another limitation may be related to the spread of L-glutamate to adjacent regions, affecting the cardiovascular responses to L-glutamate microinjection into the RVLM. For instance, the L-glutamate microinjected into the RVLM may diffuse and reach the CVLM, which contains GABAergic neurons that exert a tonic inhibition on the sympathetic premotor neurons of the RVLM (Dampney, 1994). Although CVLM is often regarded as a discrete region residing $1.0-1.5 \mathrm{~mm}$ caudal to the RVLM in the rat, barosensitive GABAergic neurons form a diffuse column of cells interspersed among other ventrolateral medullary neurons, including RVLM barosensitive neurons (Schreihofer and Guyenet, 2002). This region was first identified by Guertzeinstein (1973) in anesthetized cats by showing that the application of excitatory drugs in the CVLM region produces a marked decrease in the mean arterial pressure. Therefore, if L-glutamate has diffused from the RVLM to the CVLM, the cardiovascular responses may be a result of a summation of excitatory and inhibitory drives to sympathetic premotor neurons. If this is the case, it is more likely to occur in malnourished animals due to their smaller size.

The main finding of the present study is the lack of sympathetic modulation in malnourished rats. This is indicated by the highly linear blood pressure increase in response to L-glutamate microinjection into the RVLM. However, in previous studies our group showed that an autonomic imbalance does occur in post-weaning protein-deprived rats (Martins et al., 2011; Bezerra et al., 2011a; Bezerra et al., 2011b). This lack of modulation of sympathetic activity by the RVLM may explain, in part, the autonomic imbalance observed in previous studies of our group. This autonomic imbalance in turn may contribute to the changes observed in the cardiovascular responses to activation of the baroreflex (Loss et al., 2007), chemoreflex (Penitente et al., 2007) and von Bezold-Jarisch reflex (Bezerra et al., 2011a, 2011b). It is well established in the literature that autonomic imbalance and cardiovascular neural reflex impairment lead to hypertension and cardiovascular diseases. Whether or not such morbidities occur in our model is a matter for future long-term studies.

In conclusion, the present study suggests that malnutrition indeed affects the central mechanisms involved in cardiovascular regulation, especially regarding the glutamatergic pathways of the RVLM - the principal CNS area responsible for the modulation of sympathetic activity directed to the cardiovascular system. Further studies are needed to evaluate interaction with other neurotransmitters/ neuromodulators (e.g., GABA, NO, angiotensins) at this level. The complete understanding of the central mechanisms involved in the autonomic imbalance found in malnourished individuals could lead to the development of therapeutic strategies and governmental policies to improve public health.

\section{ACKNOWLEDGEMENTS}

We thank the Fundação de Amparo à Pesquisa do Estado de Minas Gerais (FAPEMIG), Fundação de Amparo à Pesquisa 
do Estado do Rio de Janeiro (FAPERJ), Conselho Nacional de Pesquisa (CNPq) and Coordenação de Aprimoramento de Pessoal de Nível Superior (CAPES) for financial support for the present study.

\section{REFERENCES}

AICHER, S.A., REIS, D.J., NICOLAE, R., AND MILNER, T.A. (1995). Monosynaptic projections from the medullary gigantocellular reticular formation to sympathetic preganglionic neurons in the thoracic spinal cord. J. Comp Neurol. 363, 563-580.

ARAUJO, G.C., LOPES, O.U., AND CAMPOS, R.R. (1999). Importance of glycinergic and glutamatergic synapses within the rostral ventrolateral medulla for blood pressure regulation in conscious rats. Hypertension 34, 752-755.

BARKER, D.J. (2007). The origins of the developmental origins theory. J. Intern. Med. 261, 412-417.

BENABE, J.E., AND MARTíNEZ-MALDONADO, M. (1993). Dietary modification of the renin angiotensin system. Semin. Nephrol. 13, 567572.

BERGAMASCHI, C., CAMPOS, R.R., SCHOR, N., AND LOPES, O.U. (1995). Role of the rostral ventrolateral medulla in maintenance of blood pressure in rats with Goldblatt hypertension. Hypertension 26, 11171120.

BEZERRA, V.M., XAVIER, C.H., DE MENEZES, R.C., FONTES, M.A., CARDOSO, L.M., FERNANDES, L.G., AND CHIANCA, D.A., JR. (2011a). Bezold-Jarisch reflex in sino-aortic denervated malnourished rats. Auton. Neurosci. 162, 48-53

BEZERRA, V.M., XAVIER, C.H., FERNANDES, L.G., CARDOSO, L.M., FONTES, M.A., AND CHIANCA, D.A., JR. (2011b). Sympathoinhibition to Bezold-Jarisch reflex is attenuated in protein malnourished rats. Neurosci. Lett. 488, 129-132.

BROWN, D.L., AND GUYENET, P.G. (1985). Electrophysiological study of cardiovascular neurons in the rostral ventrolateral medulla in rats. Circ. Res. 56, 359-369.

CAMPOS, R.R., AND MCALLEN, R.M. (1999). Tonic drive to sympathetic premotor neurons of rostral ventrolateral medulla from caudal pressor area neurons. Am. J. Physiol 276, R1209-R1213.

COCHRANE, K.L., AND NATHAN, M.A. (1989). Normotension in conscious rats after placement of bilateral electrolytic lesions in the rostral ventrolateral medulla. J. Auton. Nerv. Syst. 26, 199-211.

COHEN, M.S. (2004). Fetal and childhood onset of adult cardiovascular diseases. Pediatr. Clin. North Am. 51, 1697-719, x.

COLOMBARI, E., SATO, M.A., CRAVO, S.L., BERGAMASCHI, C.T., CAMPOS, R.R., JR., AND LOPES, O.U. (2001). Role of the medulla oblongata in hypertension. Hypertension 38, 549-554.

DA LUZ SANTOS, C.D., CLEMENTE, A.P., MARTINS, V.J., ALBUQUERQUE, M.P., AND SAWAYA, A.L. (2010). Adolescents with mild stunting show alterations in glucose and insulin metabolism. J. Nutr. Metab 2010, 943070

DAMPNEY, R.A. (1994). Functional organization of central pathways regulating the cardiovascular system. Physiol Rev. 74, 323-364.

DAMPNEY, R.A., AND HORIUCHI, J. (2003). Functional organisation of central cardiovascular pathways: studies using c-fos gene expression. Prog. Neurobiol. 71, 359-384.

DAMPNEY, R.A., HORIUCHI, J., TAGAWA, T., FONTES, M.A., POTTS, P.D., AND POLSON, J.W. (2003a). Medullary and supramedullary mechanisms regulating sympathetic vasomotor tone. Acta Physiol Scand. 177, 209-218.

DAMPNEY, R.A., POLSON, J.W., POTTS, P.D., HIROOKA, Y., AND HORIUCHI, J. (2003b). Functional organization of brain pathways subserving the baroreceptor reflex: studies in conscious animals using immediate early gene expression. Cell Mol. Neurobiol. 23, 597-616.

EL, F.S., SOMODY, L., GHARBI, N., KAMOUN, A., GHARIB, C., AND GAUQUELIN-KOCH, G. (1999). Effects of acute and chronic starvation on central and peripheral noradrenaline turnover, blood pressure and heart rate in the rat. Exp. Physiol 84, 357-368.

FELDBERG, W., AND GUERTZENSTEIN, P.G. (1976). Vasodepressor effects obtained by drugs acting on the ventral surface of the brain stem. J. Physiol 258, 337-355.

FRANCO, M.C., CASARINI, D.E., CARNEIRO-RAMOS, M.S., SAWAYA, A.L., BARRETO-CHAVES, M.L., AND SESSO, R. (2008). Circulating renin-angiotensin system and catecholamines in childhood: is there a role for birthweight? Clin. Sci. (Lond) 114, 375-380.
GALLO, P.V. (1981). Physiological and behavioral consequences of maternal and post-weaning protein restriction. Physiol Behav. 26, 77-84.

GOTOH, M., IGUCHI, A., TAJIMA, T., IKARI, H., AND HIROOKA, Y. (1996). Starvation reduces norepinephrine activities in both hypothalamus and heart in rats. Brain Res. 706, 351-354.

GRAY, G.E. (1989). Nutrition and dementia. J. Am. Diet. Assoc. 89, 1795-1802.

GRAY, G.E., AND GRAY, L.K. (1989). Nutritional aspects of psychiatric disorders. J. Am. Diet. Assoc. 89, 1492-1498.

GUERTZENSTEIN, P.G., AND SILVER, A. (1974). Fall in blood pressure produced from discrete regions of the ventral surface of the medulla by glycine and lesions. J. Physiol 242, 489-503.

GUYENET, P.G. (2000). Neural structures that mediate sympathoexcitation during hypoxia. Respir. Physiol 121, 147-162.

HALL, R.D. (1983). Is hippocampal function in the adult rat impaired by early protein or protein-calorie deficiencies? Dev. Psychobiol. 16, 395411.

HALL, R.D., LEAHY, J.P., AND ROBERTSON, W.M. (1983). Hyposensitivity to serotonergic stimulation in protein malnourished rats. Physiol Behav. 31, 187-195.

LIPSKI, J., KANJHAN ,R., KRUSZEWSKA, B., AND RONG, W. (1996a). Properties of presympathetic neurones in the rostral ventrolateral medulla in the rat: an intracellular study "in vivo'. J. Physiol 490 ( Pt 3), 729-744.

LIPSKI, J., KANJHAN, R., KRUSZEWSKA, B., AND RONG, W.F. (1995). Criteria for intracellular identification of pre-sympathetic neurons in the rostral ventrolateral medulla in the rat. Clin. Exp. Hypertens. 17, 51-65.

LIPSKI, J., KANJHAN, R., KRUSZEWSKA, B., RONG, W.F., AND SMITH, M. (1996b). Pre-sympathetic neurones in the rostral ventrolateral medulla of the rat: electrophysiology, morphology and relationship to adjacent neuronal groups. Acta Neurobiol. Exp. (Wars. ) 56, 373-384.

LOSS,I.O., FERNANDES, L.G., MARTINS, C.D., CARDOSO, L.M., SILVA, M.E., DIAS-DA-SILVA, V.J., MORAES ,M.F., AND CHIANCA, D.A., JR (2007). Baroreflex dysfunction in rats submitted to protein restriction Life Sci. 81, 944-950.

MACHADO, B.H., AND BONAGAMBA, L.G. (1992). Microinjection of L-glutamate into the nucleus tractus solitarii increases arterial pressure in conscious rats. Brain Res. 576, 131-138.

MACHADO, B.H., MAUAD, H., CHIANCA JUNIOR, D.A., HAIBARA, A.S., AND COLOMBARI, E. (1997). Autonomic processing of the cardiovascular reflexes in the nucleus tractus solitarii. Braz. J. Med. Biol. Res. 30, 533-543.

MARTINS, C.D., CHIANCA, D.A., JR., AND FERNANDES, L.G. (2011) Cardiac autonomic balance in rats submitted to protein restriction after weaning. Clin. Exp. Pharmacol. Physiol 38, 89-93.

MCALLEN, R.M. (1986). Action and specificity of ventral medullary vasopressor neurones in the cat. Neuroscience 18, 51-59.

MILNER, T.A., MORRISON, S.F., ABATE, C., AND REIS, D.J. (1988). Phenylethanolamine $\mathrm{N}$-methyltransferase-containing terminals synapse directly on sympathetic preganglionic neurons in the rat. Brain Res. 448 205-222.

MORRISON, S.F., MILNER, T.A., AND REIS, D.J. (1988). Reticulospinal vasomotor neurons of the rat rostral ventrolateral medulla: relationship to sympathetic nerve activity and the $\mathrm{C} 1$ adrenergic cell group. J. Neurosci. 8, 1286-1301.

OLIVEIRA, E.L., CARDOSO, L.M., PEDROSA, M.L., SILVA ,M.E., DUN, N.J., COLOMBARI, E., MORAES, M.F., AND CHIANCA, D.A., JR. (2004). A low protein diet causes an increase in the basal levels and variability of mean arterial pressure and heart rate in Fisher rats. Nutr. Neurosci. 7, 201-205.

PATEL, D., BOHLKE, M., PHATTANARUDEE, S., KABADI, S., MAHER, T.J., AND ALLY, A. (2008). Cardiovascular responses and neurotransmitter changes during blockade of angiotensin II receptors within the ventrolateral medulla. Neurosci. Res. 60, 340-348.

PAXINOS,G., AND WATSON,C. (2007). The Rat Brain in Stereotaxic Coordinates (London: Academic Press).

PENITENTE, A.R., FERNANDES, L.G., CARDOSO, L.M., SILVA, M.E., PEDROSA, M.L., SILVA, A.L., HAIBARA, A.S., MORAES, M.F., AND CHIANCA, D.A. (2007). Malnutrition enhances cardiovascular responses to chemoreflex activation in awake rats. Life Sci. 81, 609-614.

PLAGEMANN, A., DAVIDOWA, H., HARDER, T., AND DUDENHAUSEN, J.W. (2006). Developmental programming of the hypothalamus: a matter of insulin. A comment on: Horvath, T. L., Bruning, J. C.: Developmental programming of the hypothalamus: a matter of fat. Nat. Med. (2006) 12 52-53. Neuro. Endocrinol. Lett. 27, 70-72.

PLAGEMANN, A., AND HARDER, T. (2009). Hormonal programming in perinatal life: leptin and beyond. Br. J. Nutr. 101, 151-152. 
PLAGEMANN, A., HARDER, T., RAKE, A., MELCHIOR, K., ROHDE, W., AND DORNER, G. (2000). Hypothalamic nuclei are malformed in weanling offspring of low protein malnourished rat dams. J. Nutr. 130, 2582-2589.

ROSEBOOM, T.J., VAN DER MEULEN, J.H., OSMOND, C., BARKER, D.J., RAVELLI, A.C., AND BLEKER, O.P. (2000a). Plasma lipid profiles in adults after prenatal exposure to the Dutch famine. Am. J. Clin. Nutr. 72, 1101-1106.

ROSEBOOM, T.J., VAN DER MEULEN, J.H., OSMOND, C., BARKER, D.J., RAVELLI, A.C., SCHROEDER-TANKA, J.M., VAN MONTFRANS, G.A., MICHELS, R.P., AND BLEKER, O.P. (2000b). Coronary heart disease after prenatal exposure to the Dutch famine, 1944-45. Heart 84, 595-598.

ROSEBOOM, T.J., VAN DER MEULEN, J.H., RAVELLI, A.C., VAN MONTFRANS, G.A., OSMOND, C., BARKER, D.J., AND BLEKER, O.P. (1999). Blood pressure in adults after prenatal exposure to famine. J. Hypertens. 17, 325-330.

ROSS, C.A., RUGGIERO, D.A., JOH, T.H., PARK, D.H., AND REIS, D.J. (1984). Rostral ventrolateral medulla: selective projections to the thoracic autonomic cell column from the region containing $\mathrm{C} 1$ adrenaline neurons. J. Comp Neurol. 228, 168-185.

SAWAYA, A.L., MARTINS, P., HOFFMAN, D., AND ROBERTS, S.B. (2003). The link between childhood undernutrition and risk of chronic diseases in adulthood: a case study of Brazil. Nutr. Rev. 61, 168-175.

SCHREIHOFER, A.M., AND GUYENET, P.G. (2002). The baroreflex and beyond: control of sympathetic vasomotor tone by GABAergic neurons in the ventrolateral medulla. Clin. Exp. Pharmacol. Physiol 29, 514-521.
SEIDLER, F.J., BELL, J.M., AND SLOTKIN, T.A. (1990). Undernutrition and overnutrition in the neonatal rat: long-term effects on noradrenergic pathways in brain regions. Pediatr. Res. 27, 191-197.

SUN, M.K., HACKETT, J.T., AND GUYENET, P.G. (1988a). Sympathoexcitatory neurons of rostral ventrolateral medulla exhibit pacemaker properties in the presence of a glutamate-receptor antagonist. Brain Res. 438, 23-40.

SUN,M.K YOUNG, B.S, HACKETT, JT, AND GUYENET, P.G. (1988b). Reticulospinal pacemaker neurons of the rat rostral ventrolateral medulla with putative sympathoexcitatory function: an intracellular study in vitro. Brain Res. 442, 229-239.

SUN, M.K., YOUNG, B.S., HACKETT, J.T., AND GUYENET, P.G. (1988c). Rostral ventrolateral medullary neurons with intrinsic pacemaker properties are not catecholaminergic. Brain Res. 451, 345-349.

TROPIA, F.C., CARDOSO, L.M., PEDROSA, M.L., SILVA, M.E., HAIBARA,A.S., MORAES, M.F., AND CHIANCA,D.A., JR. (2001). Effects of low-protein diet on the baroreflex and Bezold-Jarisch reflex in conscious rats. Nutr. Neurosci. 4, 99-107.

UNICEF. Annual Report 2008. (2009). Available at <http:// www.unicef.org/ publications/index_49924.html>

WORLD HEALTH ORGANIZATION. (2009) Nutrition. Available at <http:/ / www.who.int/nutrition/en/>.

ZIPPEL, U., PLAGEMANN, A., AND DAVIDOWA, H. (2003). Altered action of dopamine and cholecystokinin on lateral hypothalamic neurons in rats raised under different feeding conditions. Behav. Brain Res. 147, 89-94. 
